\title{
NEGOTIATING PRE-COLONIAL HISTORY AND FUTURE DEMOCRACY: EXAMINING LAUER'S INTERVENTION ON WIREDU'S CONSENSUAL DEMOCRACY
}

\author{
Emmanuel Ifeanyi Ani \\ University of Ghana, Legon \\ Edwin Etieyibo \\ University of the Witwatersrand, South Africa
}

\begin{abstract}
Kwasi Wiredu proposed a democracy by consensus, inspired by the consensual practices of the traditional Akan of Africa. But his presentation of the traditional consensual practices has been criticized for inaccurateness. Helen Lauer embarks on what she sees as cleaning the debate of the misreading of Wiredu's presentation of traditional consensual practices by his critics. This is commendable. However, we claim that she does not succeed in the task that she set out to do. We argue that her failure partly has to do with her subscribing to a one-sided assessment of such a history, which influenced the manner she evaluated the debate and some of the fallacies that crept into analysis.
\end{abstract}

\section{INTRODUCTION}

Kwasi Wiredu, one of the most influential philosophers in Africa, proposed a consensual form of democracy as an alternative to what he sees as the divisive and polarizing effects of the multiparty competitive democracy. He does not give details of what structure such a democracy could assume, but he chiefly argues that we could think towards a consensual form of democracy inspired by the consensual practices and style of governance of traditional African societies. As a case in point, he dwells on the structure of the consensual political system of the Ashanti of Ghana, where he hails. For information about the structure of this political system, he relies on Kofi Busia's book titled, The Position of the Chief in the Modern Political System of Ashanti. Wiredu informs us that lineage is the basic political unit of this system, in which every lineage unit has a head, and the head is automatically a member of council, the governing body of the village or town (Wiredu 1996, 184). Wiredu writes, "The qualifications for lineage 


\section{EMMANUEL IFEANYIANI \& EDWIN ETIEYIBO}

headship are seniority in age, wisdom, a sense of civic responsibility, and logical persuasiveness" $(1996,184)$. He tells us that every lineage elects its head by consensus to represent it in the town council. The town councils elect their representatives to the regional councils through the same procedure, and the regional councils are consensual in electing their representatives to the national council, which is headed by the king of the Ashantis, the Asantehene. Wiredu tells us that decision at all these levels was by consensus $(1996,185)$.

Wiredu's idea of consensual democracy has drawn a fair amount of discussions and commentaries from different scholars. In this essay, our focus will be on the exercise of Helen Lauer to position Wiredu positively against some criticisms in her 2011 essay, "Negotiating Precolonial History and Future Democracy: Kwasi Wiredu and his Critics" which was published in Identity meets Nationality: Voices from the Humanities and edited by Lauer herself. In this article, Lauer embarks on what she sees as cleaning the debate of the misreading of Wiredu's presentation of traditional consensual practices by his critics. We argue that she does not succeed in her house-cleaning excise because she supported a one-sided assessment of pre-colonial history, which ultimately cannot be sustained without engaging in some fallacies and mischaracterizations of the positions of the critics.

\section{THE CONSENSUS DEBATE: WIREDU VERSUS EZE}

One notable feature of Wiredu's argument for consensual democracy has to do with the issue of rationality and the chief's role in securing consensus. Wiredu writes that contrary to deliberately fostered appearance, "the personal word of the chief is not law. His official word, on the other hand, is the consensus of his council, and it is only in this capacity that it may be law, which is why the Akans have a saying that there are no bad kings, only bad councillors" (Wiredu 1996, 185). Citing William Abraham, Wiredu reports that kingship is "more a sacred office than a political one," sacred because "a chief was supposed to be the link between the living population and their departed ancestors, who were supposed to supervise human interests from their post-mortem vantage point" (Wiredu 1996, 185). Due to this religious (and also moral) authority, the chief performed "a variety of ceremonious functions," making it politically similar to a constitutional monarch. But Wiredu $(1996,185)$ writes that this is where the similarity with a constitutional monarchy ends. In his words, "But he (the chief) was unlike a constitutional monarch in being a member (at least as a lineage personage) of the ruling council and in being in a position to exercise legitimate influence on its deliberations by virtue, not of any supposed divine inspiration but rather of whatever intrinsic persuasiveness his ideas may have" (Wiredu 1996, 185). So here, Wiredu clarifies that the chief may have divine authority, but he does not need such an authority to help him influence deliberation, he has to resort to only the persuasiveness of his ideas.

Wiredu also informs us that the adherence to the principle of consensus was a premeditated option, and that it "was based on the belief that ultimately the interests of all members of society are the same, although their perceptions of those interests maybe different" (Wiredu 1996, 185). He writes that this belief is even illustrated in an art 
motif depicting a crocodile with one stomach and two heads locked in struggle over food. The artwork is meant to teach that if the crocodiles could but realize that the food is ultimately destined for the same stomach, "the irrationality of the conflict would be manifest to them" $(1996,185)$. Is such a realization humanly possible? Wiredu tells us that the Ashanti believe it is, because they believe that "human beings have the ability eventually to cut through their differences to the rock bottom identity of interests" $(1996,185)$. And the instrument to that achievement is simply rational discussion.

On the basis of this inspiration, as well as on the basis of his dissatisfaction with multiparty competitive democracy, Wiredu $(2011,1061)$ proposes what he calls a nonparty system of democracy, in which we have political associations rather than political parties, being bodies of individuals of the same persuasions who seek public support for their points of view. These associations would operate under a constitution that encourages consensus and cooperation. Wiredu $(2011,1062)$ also suggests to remove or at least reduce some constraints of elective democracy (such as periodic elections), to permit this coalition of persons to put heads together for the good of the polity. If elections cannot be completely abandoned, then "supplementary bases of representation with relatively flexible mechanisms of election can be considered. Occupational groups, for example, could select supplementary representatives by some agreed procedure that minimizes adversarial competition as much as possible" (Wiredu 2011, 1065).

Responding to Wiredu, Emmanuel Chukwudi Eze praises Wiredu, first for initiating a "return-to-the-source" project of revisiting traditional values for revitalization in contemporary life, and second, for distinguishing between the chief's religious and moral authority on the one hand, and the intrinsic persuasiveness of his ideas on the other hand. Eze argues that with this distinction, Wiredu clearly identifies several sources of legitimation of political authority (the divine, the sacred, the ancestral, and the persuasiveness of ideas). But he disagreed with Wiredu that the chief only needed to rely on the persuasiveness of his ideas to legitimate his political authority. Eze (2000, par 14) writes:

My hypothesis is as follows. First, it is rarely, and perhaps never, the case that one of the sources of legitimation of authority listed by Wiredu exists solely and cleanly independent of the others. Second, I do not understand why we should believe that not only the Akan leader but also his subjects - the distinction is important - thought or believed that the king's or a chief's only legitimate source of exercise of political influence was "the intrinsic persuasiveness of his ideas", and that the gods and the dead are merely supposed players in the game.

Eze commends Wiredu for distinguishing between these sources of the legitimation of authority because such an exercise is needed to know what is possible (and not possible) in the now largely secularized societies, "and, certainly, religiously pluralistic African countries" (Eze 2000, par 15). But, in Eze's view, by treating the religious scaffoldings as simply "supposed", and the rational ideas as alone having the persuasive powers, Wiredu appears to be suggesting that consensus is based on the Akan belief that human interests are ultimately the same at the bottom. But Eze wonders whether it 


\section{EMMANUEL IFEANYI ANI \& EDWIN ETIEYIBO}

is indeed the Akan belief in the identity of interests, or their belief "in a shared and common past and present (carried forward in the myths of origins) that leads them to employ reason and rational discussion as a means of achieving and sustaining this shared life-form" (Eze 2000, par 17).

Eze disagrees with what he calls Wiredu's rationalistic thesis that it is the logic of ideas that makes one political idea more persuasive than the other, and tells us that any observation of successful political formation and governance would show that the exercise of public power relies heavily on mythologies and symbols, such as the flag, Motherland, "the Party," "God," "freedom," "liberation," "progress," which are all calculated to invite and demand allegiance to those subjected to them (Eze 2000, par 18). Eze (2000, par 18) writes that many of these are "simply well-formed ancestral, social, religious, or mythological fantasies that succeed in achieving their effects quite often with little or no "reason". These fantasies frequently enable and persuade peoples to participate, to collaborate, and to "see reason" with each other and act together" (Eze 2000, par 18).

Eze, therefore, concludes that what we need from Wiredu is "a more adequate reconstruction of the origins and the basis of traditional consensual democracy" (Eze 2000, par 19). In his view, it is insufficient for Wiredu to reconstruct an abstract normative basis for Ashanti political practices, but should take "adequate account of actually existing social conditions and competing interests" (Eze 2000, par 20).

Eze objects to Wiredu's claim that human interests are the same (even ultimately), and that it is ignorance that precludes contestants from seeing the sameness of interests. $\mathrm{He}$ also objects to the notion that if the heads of the two-headed crocodile realized that the food is destined for the same stomach, "the heads would change their behavior from the 'irrational' (conflictual) to the 'rational' (consensual)." Eze points out that in order to declare such conflicts between two mouths leading to the same stomach as irrational, we must first rule out "extranutritional reasons - such as aesthetic pleasure, the sheer joy of chewing food; in fact, the joy of eating! - which could accrue to one head independently of the other." (Eze 2000; par 25) He wonders why two heads would struggle over food leading to the same stomach "if there is no possibility of such headspecific primal masticatory enjoyment" (Eze 2000, par 25). In Eze's opinion, the existence of these head-specific experiences disqualifies the declaration of the struggle as "irrational" and suggests the food be shared equally between the two heads. Similarly, the existence of individual human interests (including the desire to dominate) means that they (interests) are not ultimately reconcilable "at rock bottom." Eze concludes that we must therefore revisit the conceptual basis upon which Wiredu is advocating consensual democracy.

Besides these issues raised by Eze one may also worry about some implications of Wiredu's proposed one-party system for consensual democracy. This is similar to the worry that people like Carlos Jacques has highlighted. According to Jacques (2011, 25), Wiredu's arguments for the rejection of multiparty systems are no different from those of dictators and despots who ran oppressive one-party rules in Africa. He contends that Wiredu and these despots similarly argue that the multiparty system is divisive, oppressive, and so on. Carlos cites the arguments of these despotic nationalists, such 
as Kenneth Kaunda, Sekou Toure, and Joseph Ki Zerbo to demonstrate the similarity in arguments and position. He concludes that there is no originality in Wiredu's arguments, and that the difference between Wiredu's nonparty and the one party rules of the despotic nationalists is only in name (Jacques 2011, 1026).

\section{LAUER'S INTERVENTION AND HOUSE CLEANING}

Helen Lauer begins her intervention and house cleaning by writing that the US President Barack Obama, in his first visit to the Ghanaian Parliament, mentioned that every nation "gives life to democracy in its own way, according to its own tradition..." and acknowledged consensus as one of the forms of democracy around the world (Lauer 2011, 174). She quotes this remark from Obama as a subtle endorsement of Wiredu's proposal for consensus democracy. Lauer then mentions that one of the proponents of consensus democracy is Wiredu. She writes that for over a quarter of a century, Wiredu has been advocating the adoption of pre-colonial Akan ideals of good governance in today's institutional practices. She mentions that not all his works are easy to assess, and that this may explain the "pervasive and persistent disparity between the claims attributed to Wiredu's political outlook, and the claims he has made and published about non-party, multi-party, and one party politics" (Lauer 2011, 175).

Lauer clarifies that she does not intend in her essay to determine whether Wiredu is right about the appropriateness of his proposal for a non-party democracy or his allegations of the uselessness of the multiparty system of democracy. She points out that these two issues are the focus of heated academic and political debates. She states that the aim of her essay is "to clear away misconceptions that threaten to pre-empt the potential fruitfulness of such debates" (Lauer 2011, 175). She (Lauer 2011, 175) further adds:

It is important to recognize when humanities scholars have failed to distinguish bona fide sketches of indigenous African norms (norms which differentiate African political sensibilities from other historically antagonistic cultures of social justice and stewardship) from hackneyed Eurocentric projections of a pristine, by-gone, idyllic Africa.

Lauer then clarifies that she is responding to the essays of two of Wiredu's critics: Eze (2000) and Jacques (2011). Both of these essays criticized Wiredu's proposal, and she summarizes their common themes as follows: "(i) Wiredu's advocacy of nonparty politics functions just as well to defend single-party rule and with it the suppression of free speech and political opposition, and (ii) Wiredu indulges in romanticized fantasy through his accounts of pre-colonial Akan society" (Lauer 2011, 176). Lauer argues that these criticisms depend on a reading that suppresses what Wiredu actually wrote in his works. Lauer notes that these critics focused on Wiredu's more popular essays: the one titled "Democracy and Consensus: A Plea for a Non Party Polity," which appeared in his book Cultural Universals and Particulars (first published in 1995, then in 1996 and 2000) and the one titled "The State, Civil Society, and Democracy in Africa" (presented 


\section{EMMANUEL IFEANYIANI \& EDWIN ETIEYIBO}

by Wiredu at a conference in Abidjan in 1998, and published in 2011). Lauer then points out that these critics were not aware of two of Wiredu's less widely circulated works titled, "Tradition, Democracy and Political Legitimacy in Contemporary Africa" (2001) and "Democracy by Consensus: Some Conceptual Considerations" (2001). Lauer notes, however, that Wiredu's views "have not varied substantively since those published in 1995" (Lauer 2011, 177).

In what follows we discuss some of the issues that emerge from Lauer's house cleaning exercise. We begin with that of historical realism vs fantasy. This is followed in this order by issues of valuable heritage vs anachronistic superstition, empirical conditions vs normative principles, purely rational deliberation and practical considerations.

\section{THE ISSUE OF HISTORICAL REALISM OR FANTASY}

According to Lauer, Jacques had accused Wiredu of confusing myth with historical truth and that a "romanticized, illusory" image of pre-colonial Africa as "communal or collectivist... inspires Wiredu's work (Jacques 2006, 8; cited in Lauer 2011, 177). She notes that Jacques had accused Wiredu of "committing the same unanimist illusion as Paulin Hountondji had accused Kwame Nkrumah of making in his romanticized version of pre-colonial societies in Consciencism" (Lauer 2011, 177). But Lauer notes that Wiredu had conjured nothing like a purely harmonious Akan society, and that he writes about "sharp disagreements that prevailed at all levels" and "various loci of disagreements and conflict...even within traditional councils" (Wiredu 1998, 246; cited in Lauer 2011, 177). Lauer then argues that Wiredu "neither exaggerates nor romanticises the success of pre-colonial rule" but that Wiredu only points out the contrast between notorious despots and celebrated non-despotic rulers of olden days (Wiredu 2001, 163; cited in Lauer 2011, 177). She then concludes that "it is not clear at all why the critics accuse Wiredu of fantasizing that harmony and unity were the hallmark of pre-colonial Akan society" (Lauer 2011, 177).

But how did Lauer know that the rulers of the olden days were "non-despotic?" In any case, and with due respect, it is not convincing to point out that Wiredu did not fantasize unity and harmony in traditional society by simply citing Wiredu's references to disagreements and conflict in the same traditional societies. No society's harmony and unity is measured by the absence of disagreement and conflict (since such an absence is utopian). Lauer ought to understand that references to any society's unity or harmony are made in comparative terms: such a society is not devoid of disagreements or conflict. Such a society only enjoys a bit more peace or manages its disagreements and conflict a bit better compared to other societies. When Wiredu discusses conflict in traditional Akan society (or even any other traditional society), he does so in relative terms: relative to what we see today, i.e. in the multiparty system. For example, he writes, "The claim is not that political conflict is foreign to Africa, which would be absurdly false, but only that conflict emanating from the activities of those special forms of organization called political parties is not indigenous to Africa" (Wiredu 2011, 1060). Critics are not worried about a claim by Wiredu that disagreements and conflicts were 
absent (Wiredu makes no such claim); they are rather worried that Wiredu claims that consensus as a social instrument was used to resolve all conflict so genuinely that they (conflicts) genuinely ceased (Wiredu 1996, 182).

It will be absurd for any critic to make the claim that disagreements and conflicts were absent in traditional Africans societies; for if there were no such disagreements and conflicts the question arises as to why there would be any attempt at consensus in the first place. Wiredu $(1996,185)$ indeed claims that every decision in the Ashanti kingdom was achieved through consensus and that voting never existed among them. $\mathrm{He}(2011,1063)$ even mused that every decision could be by consensus in a contemporary non-party democracy. And Wiredu $(2011,1063)$ is technically under a unanimist illusion when he claims that the Akan believed that human beings have the ability to cut through their differences to the rock bottom identity of interests through rational discussion. These are the claims worrying Wiredu's critics, and anyone would be worried about them.

Lauer further explains that Wiredu did not think there was a need for consensus if conflicts and disagreements were absent in traditional societies. She cites Wiredu as writing, "Deliberation needs not always lead to compromise" (Wiredu 1998, 247; cited in Lauer 2011, 178). But this reveals a disparity and lack of consistency within Wiredu's writings. When Wiredu writes here that deliberation needs not always lead to compromise, and writes elsewhere that every decision could possibly be by consensus (as cited in the paragraph above), Lauer needs to be concerned that Wiredu vacillates in his account of consensus in both traditional societies and in contemporary projections. She may also realize that Wiredu is quite capable of taking conflicting positions, and that it is insufficient to argue that Wiredu did not take a position by simply citing a contrary statement that he made elsewhere in his writings.

Lauer mentions that Wiredu argued that we could reach agreed action without agreeing in notion, or agree in action without agreeing in beliefs (Wiredu 2001, 243; cited in Lauer 2011, 178), and that this shows that Wiredu is not under any unanimist illusion. But Wiredu does not make it clear if he is describing the practices of the traditional Akan society, or if he is making this clarification as a prescription for contemporary deliberation. If Wiredu refers to this form of consensus as a traditional practice, one would wonder what his source of information is, and whether this information is contained in Busia's book about the Ashanti political system, which Wiredu uses as his main source of information about the Akan consensus practices (Wiredu 1996, 184). If, on the other hand, Wiredu intends this model of consensus for contemporary practice, it can be seen in similar literature, such as Larmore's "universal norm of rational dialogue" $(1987,53)$, Gutman and Thompson's proposal of the idea of the "economy of moral disagreement" $(1990,81)$, Sunstein's "incompletely theorized agreements" $(1997,111)$. Indeed, deliberation has been conceived as "... a search for an organizational solution acceptable to individuals adhering to different world views" (Wesoloska 2007, 665), in which “... we might agree on what to do without achieving agreement on why to do it" (Neblo 2007, 539).

Lauer argues that the above citations should obviate the pro-democratic anxiety of Jacques about non-party suppressing individuals' points of view. She points out 


\section{EMMANUEL IFEANYIANI \& EDWIN ETIEYIBO}

that Wiredu had opined that the very point of the communalistic ethos was "prioritizing individuals' needs and entitlements..." (Lauer 2011, 179). In a footnote, she writes that Wiredu told her this in a conversation in the Philosophy Department of the University of Ghana, on 17 April 2009. But this contradicts what Wiredu has written earlier about the very essence of the communalistic ethos, which is "the adjustment of the interests of the individual to the interests of others in society" $(2011,1061)$.

Lauer notes that Jacques is "unconvinced by the communitarian ethos" (Lauer 2011, 179). But the question is: how communal are contemporary Africans to one another today? If the intensity of communitarianism endured into contemporary Africa, then it makes sense to fashion political systems that are premised on communitarianism: systems that presuppose that contemporary Africans will be communitarian. But most African countries are in reality being torn apart by tribalism and sectionalism (see Crary 1986 and Aremu 2010), and communitarianism plays itself out only within clans and families. So it seems only logical to fear that fashioning a country-wide political system that assumes that Africans would be communal even across tribes (that requires communitarianism to work) is a mere moral exhortation and a categorical mistake.

The ancillary is that Lauer notes that Jacques fears that Wiredu's non-party proposal will end up like the one-party despotisms we have seen from early nationalists such as Amilcar Cabral, Joseph Ki-Zerbo, Jomo Kenyatta, Kwame Nkrumah, Julius Nyerere, Sekou Toure and others. These nationalists had rejected electoral politics as un-African and proposed the resurrection of African harmony as African identity, which should be re-instituted after the interference of colonialism. But they in reality were despots. Jacques $(2011,1026)$ notices no substantive difference between Wiredu's non-party proposal and their single-party proposals, and argues that Wiredu's proposal is only different in name.

Lauer responds to Jacques' argument by reminding us that Wiredu himself disparaged the one-party despotisms, including their use of the communitarian rhetoric as cover for their tyranny. She cites a passage from Wiredu:

In concluding this advocacy of a non-party system of politics, I would like to dissociate myself from any concealed hankering after a one-party system. This is especially necessary since some politicians in power wishing to create a one-party situation without a one-party designation have been known to use the banner of the non-party idea. The fundamental difference between a non-party system and a one-party one is that the former embraces the freedom of political association while the latter execrates it (Wiredu 2011, 1065).

The only feature that Wiredu mentions as distinguishing his non-party proposal and the proposal made by the single-party despots is Wiredu's last sentence in the above citation. This is the claim that the fundamental difference between the non-party and one-party systems is that the former embraces freedom of political association whilst the later execrates it. Let us assume that we wish to agree with this (quite undefended) claim from Wiredu. But Wiredu $(2011,1062)$ had argued earlier that we could 
do away with elections, so that deliberations between political associations would become non-partisan "in a deep sense." This threatens to remove the difference that Wiredu alludes to in his proposal, since an absence of elections in the real world should corrode any sense of accountability and replace it with a sense of entitlement, whether on the part of political appointees or those who do the appointing. Abolishing elections is similar to abolishing the idea that we should ask for payment receipts. We all seem to agree that it makes a difference in accountability that a recipient of millions of dollars is aware that the payer of the sum is in possession of written proof of payment. Suppose there is no such proof? Similarly, suppose there are no elections (or re-elections)? Just as dismissing the idea of taking a payment receipt is to assume too much about the honesty of the payment recipient, abolishing the idea of elections (or scaling down its scope of application) is to assume too much about the characters of the representatives chosen to occupy roles of significant social responsibility. It is, therefore, not completely wasteful that Jacques was concerned about the similarity between Wiredu's proposal and those of the single-party despots.

Of course, our point is that elections are one way of ensuring accountability. There may be other ways. But given that Wiredu has dismissed elections as being relevant, he owes it to us to tell us how he will ensure accountability, particularly if he is to free himself from the charge of Jacques that there is little to no difference between his proposal of one-party system and the practices of the single-party system by despots.

Lauer (Wiredu 2001, 242, 167; cited in Lauer 2011, 180) mentions that Wiredu "spells out in greater detail than does Jacques or Eze the contemporary threats to constructive politics posed by "one-party chicanery" and that Wiredu even described one-party systems as worse than multiparty systems, because in the multiparty there is "at least an appearance, though only an appearance, of press freedom," whilst there was "not even an appearance of press freedom" in the era of the one party system." She (Wiredu 2001, 168; cited in Lauer 2011, 181) cites that Wiredu warns of "the current temptation to confuse the pretenses of democratic deliverance to Africans with the antics of contemporary 'pseudo-democratic power holders' who manipulate 'majoritarian rule' and 'simulate consent' to suit the interests of their 'well-financed backers."'

The above passages of Wiredu cited by Lauer are revealing. They show that Wiredu is aware that politicians are mostly driven by selfish desires, and that they would always attempt to manipulate any system, whether it is a multiparty, one-party system, and therefore, Wiredu's nonparty system. The question, then, is not about which system is more normatively attractive, but which is more resistant to selfish manipulation. Is it a multiparty, one party or nonparty system? Wiredu is concerned about the selfish desires of politicians who take advantage of the multiparty and one party systems. But his nonparty proposal presumes the existence, instead, of commongood politicians or angels, and candidates who are innocent of selfish desires. He does not ask what are the vulnerabilities of his nonparty proposal to the selfish tendencies of politicians. For instance, Wiredu's proposal assumes that when we change the name 'political parties' to 'political associations,' the members of these groups would likewise undergo a moral transformation. But Wiredu's proposal does not specify any technicality, besides a change of name, that would make this moral transition to occur. 


\section{EMMANUELIFEANYIANI \& EDWIN ETIEYIBO}

Wiredu (2011, 1061-1062) had written that if the constitution makes it necessary for parties to form a coalition, then conditions conducive to cooperation and consensus are at hand. But in many African countries, this would be a condition conducive to collusion. ${ }^{1}$ And Wiredu's prescription that the non-party system can dispense fully, or at least partially, with elections, makes collusion an even greater likelihood by withdrawing the only social instrument used to compel multiparty politicians to at least a 'semblance' (in Wiredu's usage) of accountability.

Wiredu had argued that there is a semblance of press freedom in the multiparty party system but not even a semblance of this in the one party system. My argument is that the 'semblance' is a good step in the direction of press freedom. Democratic principles are not achieved over night or even in a few years. They begin (using Wiredu's term) in their semblances. A stocktaking of the growth of democratic systems should settle Wiredu's concern.

Every political system has its cost in practice. Lauer and Wiredu have repeatedly told us the costs of practicing a multiparty system of democracy. But it amounts to a one-sided assessment for them to keep away from asking themselves what would be the cost of practicing a nonparty system of democracy, and indeed to ignore the darker (totalitarian, authoritarian, etc.) side of the Akan political system that they adore and cherish. Having read Jacques' paper Lauer would have seen the confession of an Akan by the name Kwame Arhin that the Akan society was a totalitarian state (Kwame Arhin cited in Jacques 2011, 1026). She would also have read about Jacques' remark that several other scholars have observed that the Akan society was, at the very least, authoritarian (Jacques 2011, 1026). Since she has read a number of Wiredu's works, she would have seen Wiredu's complaint that the traditional Akan society was "deeply authoritarian...shot through and through with the principle of unquestioning obedience to superiors" (Wiredu 1980,4). Unquestioning obedience is normally institutionalized by organizations that require highly centralized authority, such as the military establishment. This is also evidenced in the Akan political system, and Lauer would have read Wiredu's own admission that authority in the Akan society was highly centralized (Wiredu 1996, 183-184). Indeed, she would have read Wiredu's admission that the consensual societies in Africa (he mentions the Akan and the Zulu) were also the most warlike (Wiredu 1996, 183-184). The correlation between consensus, authoritarianism, centralized authority, unitary governance, and even belligerence against out-groups, is quite plain. This correlation is not noticed in societies that manifest less enthusiasm for consensus, as Wiredu himself attests (see Wiredu 1996, 184).

Generally, we notice a correlation when we see that two or more events usually or frequently occur either together or one after another. A correlation does not necessarily imply a causal relationship (a relationship of cause and effect). But when there is a correlation, and when this correlation is consistent or recurrent, we cannot rule out causation. Wiredu and Lauer are obviously disturbed about the correlation between practicing the multiparty system and divisiveness or polarization. Indeed, they go ahead to assume without investigation that this correlation is in fact a causal relationship (multiparty as cause and divisiveness as effect). But neither Wiredu nor Lauer is disturbed about the correlation between practicing consensus and the authoritarian, belligerent 
political infrastructures that normally supports such a practice. It should, for instance, have occurred to them that the most attractive consensus decisions in traditional societies were going to war, and, according to the history of the military behavior of the Ashanti and the Zulu, conquering other African communities, taking captives, and (in the Ashanti case) selling many of these captives into the cross-Atlantic slavery to make money (Sarkodie 2010).

The above facts about politically consensual traditional societies are rude denials of the "good governance" that Lauer constantly calls the traditional consensual system. She glosses over these darker features in her adulation of pre-colonial history, since they do not fit into her picture of a glorious pre-colonial haven of adorable practices. By ignoring these features in her repeated reference to "a valuable heritage," she undermines the strength of her arguments and proposal. Indeed, she may be accused of being onesided in her assessment of the debate.

In his writings, Wiredu had argued that consensus as a mode of decision-making was a deliberate choice made by the Akan. He $(1996,186)$ writes:

I would like to emphasize that the pursuit of consensus was a deliberate effort to go beyond decision by majority opinion. It is easier to secure majority agreement than to achieve consensus. And the fact was not lost on the Ashantis. But they spurned that line of least resistance. To them, majority opinion in itself is not a good enough basis for decision making, for it deprives the minority of the right to have their will reflected in the given decision.

We are not convinced that traditional ancestors deliberately chose consensus as a method of decision-making. This is for three reasons. First, consensus is the most natural way of reaching group decisions: voting emerged with strong differences and deadlocks. So consensus is ontologically prior to voting. Opting for consensus is, as such, not a decision, as Wiredu argues. This is confirmed by our second reason, which is that research has shown that it is the only decision making mode mentioned for hunter gatherer societies (Urfalino 2014, 320). Third, is that consensus was necessitated as a result of the political, military, and economic situation of the time. Prior to the advent of the modern state, communities and kingdoms did not have a higher authority to regulate how they interacted with one another. They were, as such, in a "state of nature" (that is, a perpetual state of war with one another). The absence of a higher authority meant that you did not generally know if or when your neighboring kingdom or community would attack you. Any kingdom that felt more powerful tended generally to want to conquer its neighbor, enjoy the loot, and (during the time of transatlantic slavery) sell its captives into slavery for money. Such a period in history necessitated communities or kingdoms to be militarily circumspect and economically self-sufficient.

Nothing, therefore, was more desirable in such a period than a highly centralized authority, a "strong person" at the helms, and a tight chain of command permitting very little dissent. Of course, consensus was preferable under such a condition than voting. You do not have time to vote when you are in a perpetually insecure condition. Voting 


\section{EMMANUELIFEANYIANI \& EDWIN ETIEYIBO}

suggests that there are those who disagree, and wish to continue to disagree. But in such a situation, deviants were treated more or less as traitors, ostracized and hounded out. In such a situation, it was not a choice to adjust one's interests to those of the community: it was indeed a necessity. This means that communalism and consensus cannot be studied in isolation from the political infrastructure that made them possible (indeed necessary). It is, therefore, fallacious to admire consensus and communalism, and fail to acknowledge the foundations that supported them. But this is what Lauer does when she (in addition to Wiredu) focuses on these pleasant-looking manifestations of an otherwise severe time to live in, and describe them as a "valuable heritage." The rest of her essay then presents a false dichotomy (a fallacy whereby one presents only two choices when there are more than two). The two choices she presents are either to choose the valuable heritage of Africa or be against it. Criticizing the valuable heritage, which Eze and Jacques do, is to be against it.

We have two issues with this dichotomy. First is that one could criticize Wiredu's presentation and still be in support of some sort of consensual democracy. Second, we agree that Africa has a valuable heritage. But just because Africa has a valuable heritage does not mean that everything identified with such a past is valuable or is a valuable heritage. If consensus were favored more by the most centralized (and warlike) societies, then we would need to do our due diligence before qualifying it as part of a valuable heritage. This takes us to the part where Lauer presents Eze's position and the issue of valuable heritage.

\section{VALUABLE HERITAGE OR ANACHRONISTIC SUPERSTITION?}

The above title is in fact a section in Lauer's essay which presents a dichotomy between two items: either you believe in a valuable heritage, or you dismiss it as anachronistic superstition. If a dichotomy is false (if there are more options than the two options presented), then the proponent of such a dichotomy could only sustain it with further arguments that are themselves fallacious.

In this section, Lauer $(2011,181-182)$ chides Eze for dismissing the valuable heritage of Africa as anachronistic superstition. But this interpretation of Eze is not quite correct, and leads to a series of straw men fallacies. ${ }^{2}$ First, Lauer $(2011,181)$ writes that Eze "presupposes the widely received model of society that assumes economic class conflict is an inherent feature in the evolution of social structure." But this is a straw man. Eze is concerned about competing interests, but competing interests does not mean class conflict. Nowhere does Eze discuss class conflict, presuppose class conflict, or indirectly show awareness of class conflict. It is, therefore, uncharitable to label Eze's approach as a "class conflict" approach without any justification.

Lauer then claims that Eze sees the confidence exuded by traditional Africans in their own unity as "naïve" and irrelevant to the quest for good governance in modern Africa. But we are not aware of anywhere in his writings where Eze makes these statements, or where they could be gleaned from Eze's writings. Lauer cites a passage from Eze (2000, par 19) in support:

If the traditional mythological origins and justifications of consensual 
politics can no longer hold today (due to secularisation and religious pluralisms, for example), and it is determined that what we need today is a form of consensual politics, then we may have to (re)invent usable - even as we discard unusable - mythologies. For, even - and especially - a secular political institution, if it renounces brute force as a mode of mobilisation, needs some sort of mythology - PLATO's "truthful lies", or various forms of utopia - in order to endure.

Lauer $(2011,181)$ accuses Eze of being "impressed that Africans today have been secularized" and suggests that Eze "seems to mean they have been enlightened." But how do we ascertain these introspective states in Eze, or where do we glean them from this quote? One of the most fundamental admissions in the philosophy of mind is that we are unable to know people's introspective states. But here, Lauer suggests that she knows Eze's introspective states (that she knows what he is thinking) by reading his writings. When Lauer writes that Eze "seems to mean," she tells us that she in fact is not sure of what exactly she is interpreting. But this supposed identification of Eze's intention is to put him in a category the audience dislikes (or should dislike). By suggesting that Eze may have regarded secularization as a process of enlightenment, when Eze makes no such claim, Lauer pushes Eze's position into the cast of a proponent of modernization. The idea of modernization has earned a lot of distaste (and, frequently resentment) among a number of non-Western scholars. This insinuation should, therefore, automatically pit Eze against all the critics of modernization in non-Western societies. However, a reading of Eze would show that all Eze is emphasizing is that there are realities in modern Africa (especially pluralist realities) that make it difficult, if not impossible, for the homogenous and unitary social structures that sustained consensus in traditional societies to be replicated.

Let us identify a few more straw men arguments that Lauer committed against Eze. One is the quote: "Eze says that African people no longer believe in the sacred powers of their chiefs, whose authority used to be legitimized by the belief that they are divine links with ancestors" (Lauer 2011, 182). Another is this: "It was the magico-mythological beliefs in ancestral power that Eze says legitimated traditional African authority. So he concludes that the ancient Akan style of leadership has lost irreparably its former utility" (Lauer 2011, 182). Eze did not say that political authority in traditional Africa was legitimated by a magico-mythological belief. What he did was ask a question, which we quote:

But which is the fundamental belief; one might ask: is it the belief in the power of reason that led the Ashantis to believe that »ultimately the interests of all members of society are the same«, or is it the power of their belief in a shared and common past and future (carried forward in the myths of origins) that leads them to the employment of reason and rational discussion as a means of achieving and sustaining this shared life-form? (Eze 2000, par 17).

So Eze refers to the power of "belief in a shared and common past and future (carried forward in the myths of origins)," and Lauer interprets, "It was the magico- 


\section{EMMANUEL IFEANYI ANI \& EDWIN ETIEYIBO}

mythological beliefs in ancestral power that Eze says legitimated traditional African authority." First, Lauer removes the phrase "of origin" from Eze's "myths of origins" and simply refers to "myth," which means a widely held view that is false. She then adds "magic" to "myth." She does not stop here, but likens Eze's account to that of LevyBruhl, and then offers this interpretation of Eze:

The endless debating of the elders was tolerated most likely because these rituals of governance were conducted in the hocus-pocus atmosphere of ancestral power and spiritual forces, so that people believed naively Levy-Bruhl would have said they believed pre-logically - that they were bound together in a mystical unity (Lauer 2011, 182).

But this is a series of straw men. A myth of origin (to stick to Eze's terminology) has no necessary relationship with magic. A myth of origin simply means a traditional account of the early history of a society, which may be true or not, but created to embody the worldview and ideals of such a society, and to elicit patriotism or feeling of belongingness of members of such a society. Second, every traditional or ancient society has a myth of origins, and Eze makes no special accusation by alluding the same to the Akan. Third, many traditional societies used consensus for most of their decisions. So if such societies generally have their unifying myths and practiced consensus, there is nothing special about the question Eze raises about the Akan.

What Eze is hinting at, which Lauer shies away from presenting in its true form, is the fact that the two (myth of origin and consensus in decision making) are correlations of common ancestry, a commodity that is lacking in the highly pluralist urban societies we have today. And Eze's argument is that it is naïve to selectively pick and revitalize the practice of consensus in total abstraction from the social infrastructure that enabled it. In short, Eze is saying that consensus as a rule of deliberation does not operate in a vacuum: if a set of enabling conditions are no longer available in a new context, insisting on a consensus regime demands erecting another set of enabling conditions in replacement.

\section{THE ISSUE OF EMPIRICAL CONDITIONS VERSUS NORMATIVE PRINCIPLES}

Lauer then expresses her first (and only) real objection in her essay. She (2011, 182) argues that Eze fails to distinguish between "the empirical conditions of governance" and the "normative principles" that legitimate a specified form of leadership. She $(2011,182)$ clarifies that the empirical conditions include "the populace's shared views of their leadership at different historical moments." She argues that we should focus on the normative principles legitimating a specified form of leadership, rather than what the people think about the leadership, even across history. She $(2011,182)$ writes that Wiredu is concerned about "the legitimacy and feasibility of adopting a timeless and enduring political ethos inherited from precolonial times" and that it is not about whether Wiredu "attributes an inordinate amount of contemporary common sense 
to the ancients." Lauer $(2011,182)$ writes that the reason why empirical conditions of governance do not matter in assessing the normative justification for a style of governance is that "the legitimacy of any society's governing institutions does not depend upon the fact of what this or that person actually believes at a given time."

The above argument is incorrect on at least two counts (if not all counts). First, normative principles cannot do without empirical conditions in determining the legitimacy of a style of governance. And the unity of members of a polity is among such empirical conditions. It takes a lot of unity among members of a polity to routinely reach consensus on a broad range of issues - indeed, to reach more consensus than voting. Wiredu $(1996,183)$ even claims that voting never existed among the Akan. The quite obvious source of this unity in traditional societies was common ancestry and language. Eze's central argument is that this source is absent from modern urbanized societies, and, therefore, an alternative source of a high level of unity must be provided by those who insist on advocating a democracy by consensus in contemporary society. Lauer's objection amounts to saying that this is not important, only the normative attractiveness of consensus is sufficient to justify its practice anywhere and anytime.

Second is that Wiredu's proposal fails even at the normative level. The only superior normative value of consensus is that it secures the agreement of all who partook in a deliberation leading to the consensus decision. But this is unanimity, which Kibujjo Kalumba, (2015, 104-108) another proponent of consensus, has agreed is too high a moral requirement. If Wiredu, Lauer and other proponents of consensus democracy do not mean democracy by unanimity, they need to specify what exactly is the kind of consensus they are proposing, and also roll out a practical or realistically workable framework of the democratic infrastructure they have in mind. This is not the work of political scientists, who would need to accept the normative attractiveness of consensus in the first place. To stay (and remain) at the abstract level of the normative attractiveness or "inspiring ideal" of consensus is to continue to stay vague and open ended enough to avoid closer scrutiny of any framework of governance they may propose or outline.

\section{THE ISSUE OF PURELY RATIONAL DELIBERATION}

To make plainer what she understands as Eze's mistake, Lauer cites two analogies. First is an analogy about the death of the British Princess Diana. Lauer tells us that many Britons believed that the Princess is so divinely fortified that she could not possibly perish in such a way. But Lauer $(2011,183)$ reminds us that the laws of physics governing the causes and effects of accidents are indifferent to pedigree. She also mentions that during the Cold War, many American fundamentalists believed superstitiously that they would "move up literally in Holy Rapture away from the hellfire affected by a potential nuclear apocalypse" $(2011,183)$. Lauer cites these analogies to show that our superstitious beliefs do not prevent the laws of physics and nature from taking their course. These analogies, therefore, suggest that Eze denied the role of reason in traditional Akan deliberation because he alluded to respect for the king's divine authority. 


\section{EMMANUEL IFEANYI ANI \& EDWIN ETIEYIBO}

But these analogies are based on an incorrect reading of Eze. Let us cite Eze directly, "First, it is rarely, and perhaps never, the case that one of the sources of legitimation of authority listed by Wiredu (moral authority, religious authority, the intrinsic persuasiveness of ideas) exists solely and cleanly independent of the others" (2000, par 14). Reading Eze, therefore, perceptions of the king's moral and religious authority cannot serve as a mechanism of deliberation without reason. Neither can reason serve as a deliberative mechanism without these perceptions. Eze is not accusing the Akan of replacing rationality with superstition as the mechanism for deliberating. Eze is saying that deliberation is not a purely rational activity. Over the years, Emmanuel Ani (2014) has developed this point made by Eze to make it quite clear. Two thousand years before Eze, Aristotle (2004) told us that there are three components of persuasion: ethos (the perceived character and trustworthiness of the persuader), pathos (the persuader's manner, attitude, or emotion in persuading), and logos (the logic of the persuader). In Aristotle's understanding, we are not simply persuaded by reason, we also consider the integrity of the source of the message, and the attitude in which the message is delivered. It is interesting to note that Aristotle listed integrity and attitude before logic, although Ani $(2014,349-351)$ has revised this listing in another article.

We are more likely to consider the perceived integrity or trustworthiness of the messenger or persuader when we are unable to logically determine the veracity of the message. This is because logic cannot assess every issue in the world. If, for example, we are presented with two diagnoses of the ailment of a child, and we lack the medical education to ascertain the veracity of the diagnoses, we may have to trust the integrity of a trained physician. As such, we would prefer the diagnosis of the trained physician to that of a quack (and even to ours). The point simply is that we lack adequate information to deliberate properly (or logically) on the matter, and have to lean on the perceived trustworthiness of a recognized expert on this particular issue of deliberation.

When we discuss purely mathematical or empirically straightforward issues, reason or logic alone leads us to conclusions and agreements. When, for instance, we ask ourselves what is the result of adding 2 and 2, we do not need the social status of any of the participants in the deliberation to know that the answer is 4 . But these mathematical issues form only a small percentage of issues we normally deliberate upon. When, for instance we have to make a decision on an issue between two or multiple options that are not clearly ranked according to right or wrong, correct or incorrect, then the opinion or preference of the dominant participants in the deliberation would carry more weight, or at least be given first consideration. These kinds of issues, where a choice or decision can go one way or another without harming logic, or where choices are not really contradictory to one another, are what we would call gray area issues. To the extent that logic is unable to sort such issues, it (logic) is aided by non-logical factors in arriving at conclusions or agreements. Logic, therefore, is not entirely (or cleanly) responsible for all the decisions that result from deliberation. Sociological factors such as social status, religious beliefs, political ideologies, even emotions such as fear, courage, prudence, and human qualities such as tactics, interests, and other considerations that are not necessarily logical, fill in the gaps in gray area issues that logic could not entirely fill. This fact is true for the entire human species as well as for the traditional Akan. 
This is why the opinion of the chief would carry more weight if we are deliberating to choose between two options that are both not bad and no one has presented clear arguments to show that one option is clearly better or has more value than the other. The ability of sociological considerations (such as expertise and social status) to feature more in our deliberative choices depends on the elusiveness of information for clear preference, the closeness in competition between two or more proposed alternatives, or the logical or empirical intractability of the issue at hand. Again, this shortage of information and tractability (in many issues) is a fact that faces us every day as human beings.

Interests also play roles in deliberation leading to decisions. And interests are not always rational or logical. Interests are, therefore, mostly in the 'non-logical' category of factors affecting deliberation. They strengthen the thesis that deliberation is not always purely logical. We could, for instance, pose the question: was the frequent Ashanti decision to go to war always and necessarily driven by pure logic? Is it possible that interests also played occasional roles? Aside interests, could there be other factors involved apart from logic or reason in reaching at least some of such decisions? Apart from logic, then, we have, in the non-logical category, interests, beliefs (including superstitious beliefs), respect for social statuses, levels of cultural, religious homogeneity or heterogeneity, and so forth, all affecting deliberation apart from reason.

Eze is therefore not saying that logic was lost to the Akan when he says that deliberation could also be impacted by superstitious beliefs about the religious authority of the chief or king. Every traditional society had appreciable levels of superstition, and the Akan traditional society could not have been an exception. But beyond superstition, Eze is arguing broadly that in considering such a high ideal as consensus for practice in contemporary society, we must consider the non-rational factors that aided routine consensus in traditional societies, and find replacements for those of such factors that are no longer available in contemporary societies.

\section{ON PRACTICAL CONSIDERATIONS}

Turning away from Wiredu's critics, Lauer tells us to reconsider the merits of Wiredu's proposal. She tells us that whatever the merit of his non-party proposal may be, Wiredu is "spot-on when he highlights the dysfunctions and incoherencies intrinsic to electoral politics as conducted in the US and UK" (Lauer 2011, 185). She (Lauer 2011, 185-186) writes:

... in those self-defeating technocracies, compromise is the mark of political incompetence. The strength and desirability of elected representatives is measured characteristically by their capacity to stall, obstruct, thwart, if not obliterate the effectiveness of their opposition party rivals. Yet in those 'culture[s] of conflict', the very raison d'etre of a political party vanishes without a robust opposition to pit against and knock around.

As we could see in the earlier quotation, Lauer makes it clear that she and Wiredu 


\section{EMMANUELIFEANYIANI \& EDWIN ETIEYIBO}

are referring to "electoral politics." But which is the greater evil? Is it the polarization generated from an institutionalized competing for power, or it the self-entitlement, vanity, and corruption of unelected rulers? Lauer complains about the divisiveness of elective leadership, but stops at telling us whether she prefers unelected leadership. The silence is itself problematic. When public office holders in a multiparty system contribute at all to society or take their offices serious in any way, they do not always do so because they really wish to. They are, more often, compelled to do so because the institutionalized political opposition would gain the upper hand if they did not. Without such a constraining arrangement, we are left to the mercy of the free intentions (and, therefore, moral capacity) of leaders. And we know from the long history of despotism and irresponsible leadership that leaders in the real world do not generally possess the moral capacity that Wiredu and Lauer's positions assume.

Lauer $(2011,186)$ begins her conclusion by writing:

The purpose of this essay has been to appreciate the degree to which experts in African political thought can fail to represent one particular interpretation of democracy, one that is explicitly indigenous to Africa, an interpretation of democracy to which the first African American US president tacitly paid tribute in his first speech on the African continent.

The citation of President Obama as supporting consensus is an appeal to unqualified authority. Obama may have been a United States President. But he is not an expert on consensus. The citation is also a propaganda technique called cognitive dissonance, a particular variety of appealing to authority. When a person notices that an idea has critics, she could choose to cite a well-liked personality as supporting the idea, in the hope that critics or skeptics could face a false dichotomy of either liking the personality and liking the idea, or disliking the idea and disliking the personality along with the idea.

Lauer purports that she values debates, and that the debate about African styles of leadership should be kept alive. She $(2011,187)$ writes, "For what is at stake here is the general utility of academic debate as a source of inspiration and clarification actualising the near and distant political future. There is a very specific, substantive reason to keep alive the African controversy over appropriate political leadership." Yet, a few sentences down the same page, she $(2011,187)$ writes:

So it is that, in order to remain intact and effective, the most compelling and potent aspects of indigenous rule must be hidden from the international gaze - hidden in the sense that their utility and intrinsic values are neither readily detectable first hand nor readily describable through the lenses and vocabularies afforded to those who use as their mother tongue the international languages of former colonisers.

There is an underlying assumption that when an indigenous value is exposed to 
international debate, the value would be destroyed by the employment of colonial instruments. But this general assumption is contestable because it presupposes that debates are exercises where sophistry simply prevails. Moreover, we have seen that a similar assumption that Lauer makes earlier against Eze is unsuccessful. We believe that anything that has any value (and that will be of benefit to humanity) should be thrown open to debate. However, the passage seems to back away from this idea. Rather than pushing for international debate on traditional norms in order to expose their merits, Lauer seem to be interested in keeping them secret and esoteric. This attitude is one that is, for us, difficult to understand.

\section{CONCLUSION}

What then do we have, in summation, of Lauer's essay? This is an article that purports to clean the consensus debate of errors in interpreting Wiredu, allegedly committed by two of his critics. But as we have presented, Lauer's reading of their interpretation is incorrect, and their interpretations of Wiredu escape her criticism. In being an essay that purports to clean the house, Lauer poses as a neutral umpire. She $(2011,187)$ writes, “ $\ldots$ the motivation for correcting gross error in the secondary literature goes beyond a penchant for scrupulous scholarship; nor is it a strategy for polishing one side of an argument to appear more attractive than the other." But in posing as a neutral judge, she is quite judgmental when she refers to the two political systems under comparison. For examples, she refers to traditional consensual style of governance as "a timeless and enduring political ethos..." $(2011,183)$ or "valuable heritage" (2011, 181 ) whilst she refers to multiparty democracies as "self-defeating technocracies" (2011, 185). For someone who purports to be a disciplining umpire, Lauer's references to the rival systems are in fact value judgments, betraying her preference for Wiredu's proposal. The value judgments disqualify her from being a neutral referee, and put her firmly in support of Wiredu's proposal. What is required of such a position is for Lauer to advance arguments, in the form of reasons, to demonstrate why she considers traditional consensual systems as timeless and enduring whilst multiparty systems are selfdefeating. However, Lauer does not do this. She $(2011,175)$ writes:

The textual data canvassed here will not determine whether or not Wiredu is correct about the fitness of non-party politics in contemporary African democracies, nor whether he is right in saying that competitive multiparty campaigning is useless for facilitating good democratic governance on the African continent today.

It is good to note that her description of multiparty democracies as "self-defeating technocracies" denies this disclaimer quite directly. So in the end, we are back to where we began in the essay, after a not very valuable trip, padded with informal fallacies. The least we expect from a house cleaning exercise is to be fair and free of these techniques. 
130 EMMANUELIFEANYIANI \& EDWIN ETIEYIBO

\section{NOTES}

1. Elsewhere Ani has developed this thesis in chapter six of a yet to be published book project titled Disentangling Consensual Democracy.

2. A straw man is to accuse an opponent of a position that he or she did not take, usually a worse position, to pave way for an easy rebuke of the accused position, either by the accuser or usually by the audience.

\section{R E F E R E N C E S}

Ani, Emmanuel I. 2014. On traditional African consensual rationality. The Journal of Political Philosophy 22(3): 342-365.

Aremu, Johnson O. 2010. Conflicts in Africa: Meaning, causes, impact and solution. African Research Review 4(4): 549-560.

Aristotle, 2004, Rhetorics. Translated by W. Rhys Roberts. New York: Courier Dover Publications, also available at http://www.bocc.ubi.pt/pag/Aristotle-rhetoric.pdf.

Busia, Kofi. 1968. The position of the chief in the modern political system of Ashanti. London: Frank Cass.

Crary, David. 1986. African continent tormented by tribal conflicts: Problem has triggered wars, toppled governments and wrecked courtships. Los Angeles Times (23 March). Available at: http://articles.latimes.com/1986-03-23/news/mn-5583_1_tribal-conflicts (accessed 4 December 2018).

Eze, Emmanuel C., Democracy or consensus? Response to Wiredu. Polylog 2000, Available on http://them.polylog.org/2/fee-en.htm.

Gutmann, Amy and Thompson, Dennis. 1990. Moral conflict and political consensus. Ethics 101(1): 64-88.

Jacques, Carlos. 2011. Alterity in the discourse of African philosophy: A forgotten absence. In Reclaiming the human sciences through African perspectives. Vol II. Edited by Helen Lauer and Kofi Ayidoho. Legon-Accra: Sub-Saharan Publishers, pp. 1017-1030.

Kalumba, Kibujjo M. 2015. Consensus and federalism in contemporary African political philosophy. Philosophical Papers 44(1): 103-119.

Larmore, Charles. 1987. Patterns of moral complexity. Cambridge: Cambridge University Press.

Lauer, Helen. 2011. Negotiating precolonial history and future democracy: Kwasi Wiredu and his critics. In Identity meets nationality: Voices from the humanities. Edited by Helen Lauer. Legon-Accra: Sub-Saharan Publishers.

Neblo, Michael A. 2007. Family disputes in defining and measuring deliberation. Swiss Political Science Review 13: 4: 527-57.

Sarkodie, Jake Akwasi. 2010. Ashanti Empire blamed for slavery. Ghana Web (General News, 28 April). Available at: https://www.ghanaweb.com/GhanaHomePage/ NewsArchive/AshantiEmpire-blamed-for-slavery-180918 (accessed 11 April 2018).

Sunstein, Cass. 1997. Deliberation, democracy, disagreement. In Justice and democracy:

Philosophia: International Journal of Philosophy

ISSN 2244-1875

Vol. 20, No. 1, January 2019 
Cross-cultural perspectives. Edited by R. Bontekoe and M. Stepaniants. Honolulu: University of Hawaii Press, pp. 93-117.

Urfalino, Philippe. 2014. The rule of non-opposition: Opening up decision making by consensus. Journal of Political Philosophy 22(3): 320-341.

Wesolowska, Elzbieta. 2007. Social processes of antagonism and synergy in deliberating groups. Swiss Political Science Review 13 (4), pp. 663-80.

Wiredu, Kwasi. 1980. Philosophy and an African culture. Cambridge: Cambridge University Press.

. 1996. Cultural universals and particulars. Bloomington and Indianapolis: Indiana University Press.

.2001a. Tradition, democracy and political legitimacy in contemporary Africa. Rewriting Africa: Toward renaissance or collapse? Japan Centre for Area Studies JCAS Symposium Series no. 14, Osaka, Japan: National Museum of Ethnology, pp. 161-172.

.2001b. Democracy by consensus: Some conceptual considerations. Philosophical Papers 30(3): 227-244.

2011. State, civil society and democracy in Africa. In Reclaiming the human sciences Vol II. Edited by Helen Lauer and Kofi Ayidoho. Legon-Accra: SubSaharan Publishers, pp. 1055-1066.

Submitted: 4 April 2018; revised 5 December 2018 